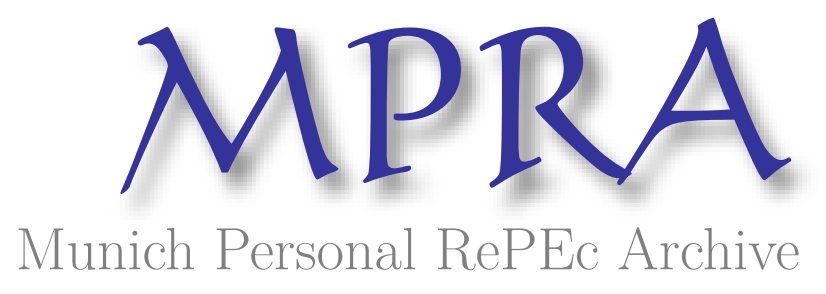

\title{
Financial Holding Company Structure for India
}

\author{
Swamy, Vighneswara \\ IBS - Hyderabad
}

2012

Online at https://mpra.ub.uni-muenchen.de/47515/

MPRA Paper No. 47515, posted 13 Jun 2013 05:27 UTC 


\title{
FINANCIAL HOLDING COMPANY STRUCTURE FOR INDIA
}

\author{
Vighneswara Swamy Ph.D \\ IBS - Hyderabad
}

\begin{abstract}
Indian banking sector is passing through another crucial phase in its evolution with the Reserve Bank of India proposing the formation of holding companies in banking groups. This paper offers an analytical discussion about the proposed financial holding company (FHC) or banking holding company (BHC) that is claimed to offer considerable advantages as the banks will be much better protected against possible adverse effects from the activities of their non-banking financial subsidiaries. The paper recommends that the financial holding company (FHC) model ought to be pursued as a preferred model for the financial sector in India. In addition, the FHC model can be extended to all large financial groups - irrespective of whether they contain a bank or not. Accordingly, there can be Banking FHCs controlling a bank and Non-banking FHCs, which do not contain a bank in the group.
\end{abstract}

JEL classification: $\quad$ G 21, G 28, G29

Keywords: $\quad$ Banking Risk; Diversification, Financial Holding Company, Banking Holding Company

*Dr. Vighneswara Swamy, Associate Professor, Department of Finance, IBS-Hyderabad, INDIA, www.ibsindia.org, E-mail: vighneswar@ibsindia.org, Phone: +91-8417-236660 Ext.: 6109, Mobile: +9109705096919 


\section{FINANCIAL HOLDING COMPANY STRUCTURE FOR INDIA}

\section{Introduction}

The changing landscape of the global financial industry coupled with increasing M\&A activities among financial institutions and increasing joint ventures and strategic alliances among financial institutions calls for certain tectonic shift in Indian financial sector too. Some of the underlying causes of global financial consolidation can be ascribed to cost savings and revenue enhancements, financial deregulation and globalization owing to technological and financial innovation, changing consumer demand, corporate and institutional demand, and shareholder pressure on financial performance. Globally, the most prevalent models under which financial conglomerates are organised straddle the entire spectrum, comprising a holding company model, wherein all bank as well as non-bank financial activities are undertaken through distinct subsidiaries of a parent holding company. A bank-subsidiary model requires the banks floating subsidiaries under them to undertake various non-bank financial activities; and a universal banking model necessitates that all financial activities are undertaken within a single entity.

Indian financial services sector has also been witnessing a rise in the emergence of financial conglomerates. With the enlargement in the scope of the financial activities driven by the need for diversification of business lines to control the enterprise-wide risk, some of the players are also experimenting with structures hitherto unfamiliar in India. In this context, it is considered timely to take a review of some of the conglomerate structures, assess their suitability for the country given the prevailing legal, regulatory and accounting framework, and highlight the regulatory and supervisory concerns for the Reserve Bank emanating from such structures.

The subject of the type of corporate form embraced by financial groups in India for undertaking a range of financial activities has gained significance from two distinctive, interrelated, perspectives. The first being efficient corporate management within the groups meeting the growth and capital requirements of diverse entities. The second is the degree of regulatory comfort with diverse models, especially about the concerns relating to contagion risks. 
Banks, at present, in India are organized under the Bank-Subsidiary Model (BSM) in which the bank is the parent of all the subsidiaries of the group. The need and feasibility of introducing a financial holding company model in the Indian context is necessitated from the lessons drawn from the global financial crisis.

\section{Financial Holding Companies - Global experience}

Financial holding companies are entities that control regulated financial intermediaries: typically depository institutions (such as commercial banks or savings associations), insurance companies, or securities firms (Howell E. Jackson, 1997). Predominantly two holding company models for bank related conglomerates viz, Bank Holding Company (BHC) Model and Financial Holding Company (FHC) Model are observed worldwide.

1. BHC Model: BHCs are companies that own or control one or more banks. In USA, the Federal Reserve regulates these companies. They were first introduced in Bank Holding Company Act of 1956. Further, these companies can make only limited investments in the non-banking companies.

2. FHC Model: FHCs are companies that own or control one or more banks or nonbank financial companies. In USA, FHCs were created by the Gramm-Leach-Bliley (GLB) Act of 1999 as a way to expand the financial services activities of BHCs. GLB Act permits banks, securities firms and insurance companies to affiliate with each other through the FHC structure. FHCs can engage in activities other than banking as long as they are financial in nature. The most important of these are securities underwriting and dealing, insurance underwriting, insurance agency activities and merchant banking. The requirement to have bank in the financial group is prerequisite for qualifying as an $\mathrm{FHC}$ in USA.

At present, there are more than 600 FHCs in USA. Most of them are the BHCs, which have elected to become FHCs under the GLB Act. FHCs control approximately $80 \%$ of the entire banking system in USA. Other than USA, Canada, UK, Japan, France and some Emerging Asia countries such as Taiwan, Korea, Singapore and Hong Kong also have the FHC as a model of organization. 
In the case of European Union (EU), financial conglomerates are organized through a holding company model. Australia, based on recommendations of its Wallis Commission, has allowed the holding company model as part of liberalization of the range of activities that can be carried out within a conglomerate group containing banks. In Korea, it was the Asian crisis which triggered the move towards the holding company model in the financial sector.

The recent global financial crisis has nevertheless reignited the debate on the nature and scope of the banks' involvement with securities activities. The Volcker rule, which stipulates clear-cut separation between banking and proprietary trading and investments in hedge funds and private equity is at the heart of the legislative reforms in this direction. It is clearly an expression of concerns regarding the so-called marriage of traditional banking with investment banking.

With regard to the form of conglomeration is concerned, the crisis can be termed as model agnostic. The FHC model in the US could not guarantee isolation of banks from non-bank financial activities as the Special Purpose Vehicle (SPV) structure allowed banks to undertake many activities directly. On the other hand, in EU where the Bank-Subsidiary Model was more predominant, the insufficiencies in consolidated capital requirements at the bank level were found to be obvious. Both under Holding Company Model (HCM) and Bank-Subsidiary Model (BSM), the individual banks were found to be under-capitalised even though the banking groups claimed to have adequate capital at the consolidated level.

\section{Major Types of Financial Holding Companies Structures}

A typical bank-centric organization structure, which is currently followed in India is shown below.

Figure-1: A Typical Bank-Centric Organization Structure-Bank Subsidiary Model

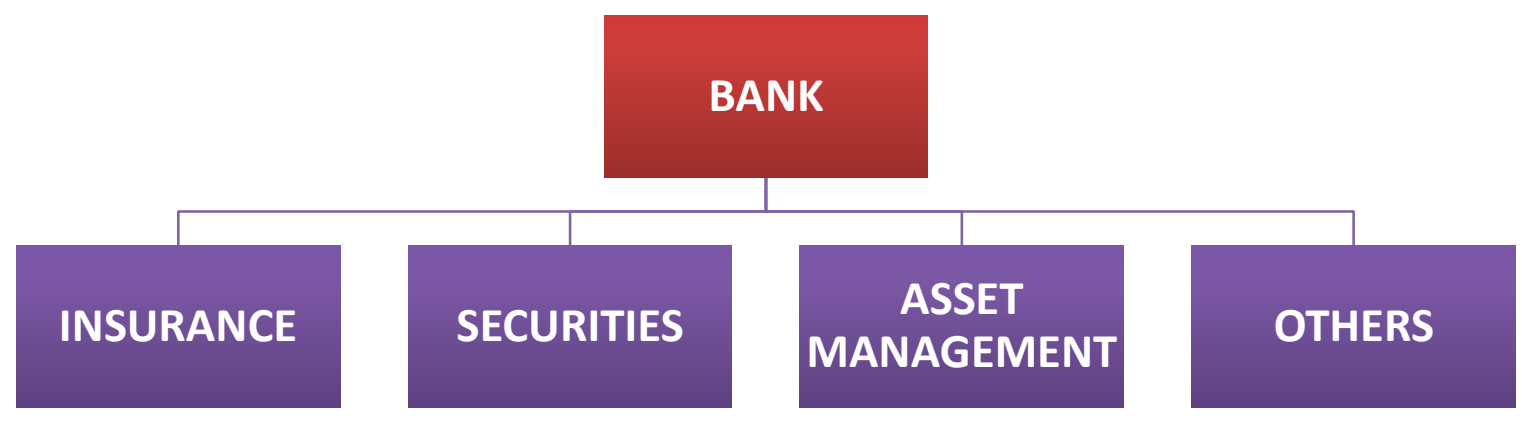


In a banking or financial group, a holding company can be the parent of the group or an intermediate holding company. A multi-layered financial conglomerate may also have a few tiers of intermediate holding companies apart from the holding company at the top. Organisational structure of a typical FHC with a main banking subsidiary, other banking subsidiaries and other non-banking financial subsidiaries is given in Figure 2.

Figure 2: A Financial Conglomerate with Holding Company at the Apex

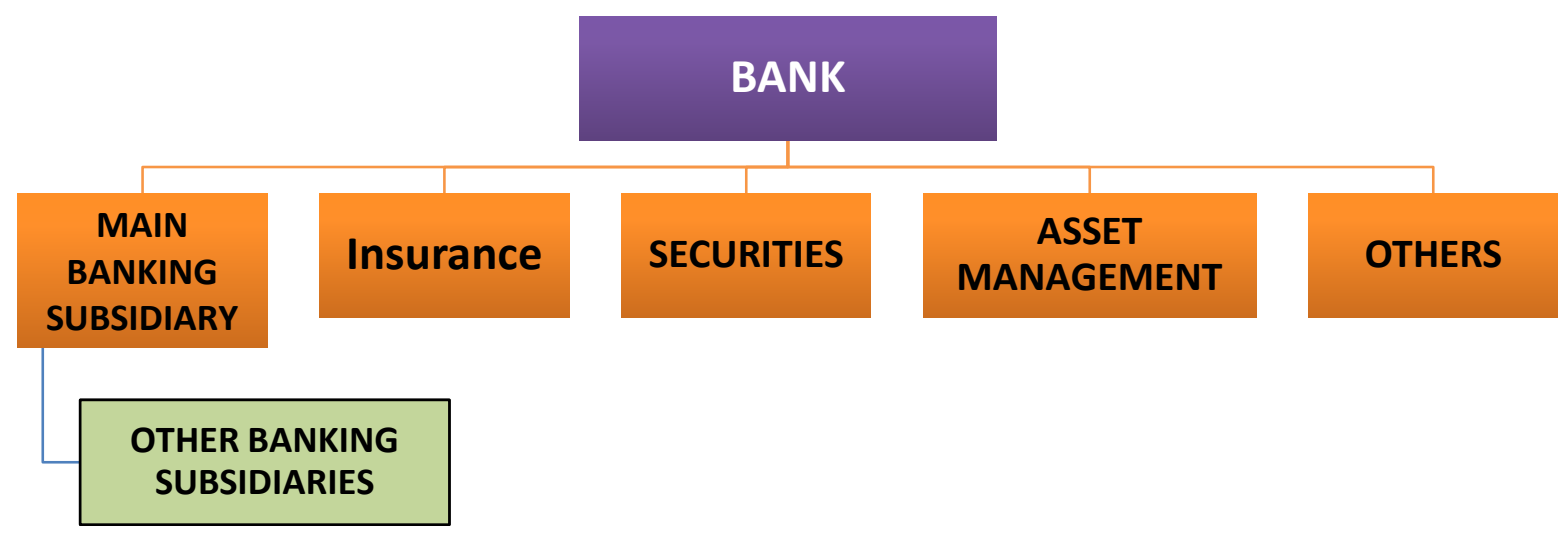

A financial conglomerate with a parent holding company and also an intermediate holding company is illustrated below.

Figure 3: A Financial Conglomerate with Holding Company at the Apex as well as an Intermediate Holding Company

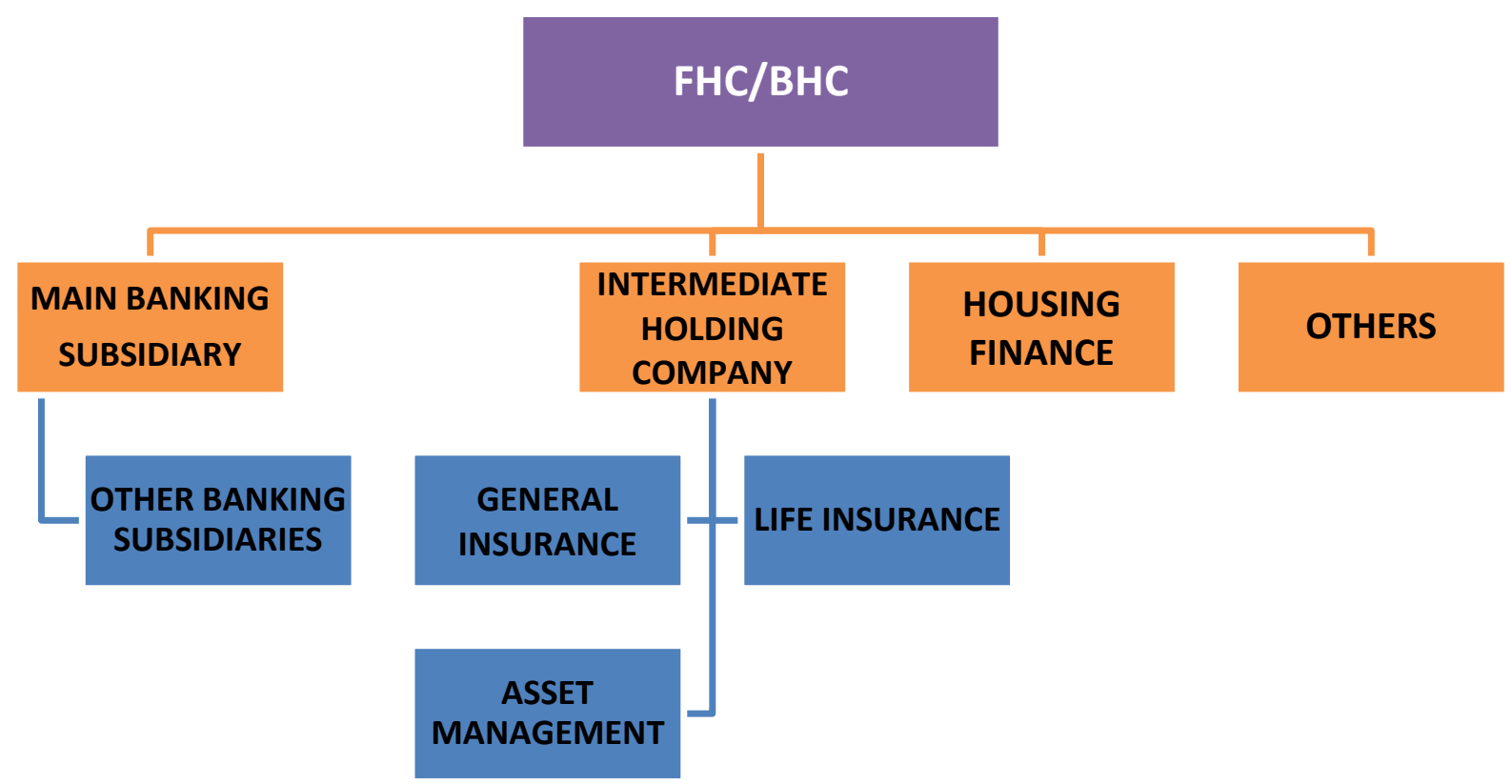




\section{Holding Companies in Banking Groups}

Across the globe, deregulation and financial consolidation have given way to the development of Financial Holding Companies-allowing commercial banking, insurance, investment banking, and other financial activities to be conducted under the same corporate umbrella. There are several ways of conducting different financial services in the same organization, like;

- The Universal Bank as currently practiced in Germany, where all financial services are done within the bank;

- The Bank Subsidiary Model, where non-banking activities are done in separately constituted subsidiaries of the bank;

- The Bank Holding Company model, where non-banking activities are done in firms owned by a parent company that also owns the bank.

All the above conglomerate models can have one or more layers of intermediate holding companies.

Transforming into a bank holding company makes it easier for the firm to raise capital than as a traditional bank. The holding company can assume debt of shareholders on a tax-free basis, borrow money, acquire other banks and non-bank entities more easily, and issue stock with greater regulatory ease. It also has a greater legal authority to conduct share repurchases of its own stock.

\section{The Bank Subsidiary Model vs. the Holding Company Model}

On evaluating the comparative pros and cons of the equally prevalent Holding Company Model (HCM) vis-à-vis the Bank Subsidiary Model (BSM), one can observe that the universal banking model was not really an option in the Indian context given the entityfocused regulatory approach and historical evolution of financial conglomerates.

While the issues of conflict of interest and moral hazard arising from affiliation are there for all financial sector entities, these are most pronounced in case of banks because of the safety net considerations. Although there is no clear evidence that the traditional non-banking activities increase risk for banks, the recent financial crisis has proved beyond doubt that banks' undue involvement in the off-balance sheet activities and sponsoring of SPVs could increase risk for them. Banks will have reputational risks, both under BSM and HCM models. 
Under both BSM and HCM, the parent company straight away benefits from profits earned by the subsidiary. On the other hand, there is a difference in the nature of the exposure of the banks to the losses from the non-banking activities. While under BSM, the bank reaps the profits and bears the losses (depending on its equity stake and credit extended) associated with these activities, a bank owned by a holding company with non-bank affiliates, instead, is not directly exposed to non-bank losses, but at the same time may not benefit from any profits earned by non-bank affiliates.

One of the key risks postured by the BSM model is that the parent bank is directly exposed to the functioning of various subsidiaries and any loss suffered by the subsidiaries inevitably affects the bank balance sheets. Further, the obvious risk from connexion of banks with nonbanks is the risk of transmission to non-bank affiliates of a subsidy implicit for banks in the safety net, deposit insurance, access to central bank liquidity, access to payment systems, with the attendant moral hazard. This subsidisation is more readily transferred to a subsidiary of bank and to some extent can be reduced through the holding company structure.

In terms of philosophy and approach to regulation, FHC model makes it cleaner to focus on group-wide risks centrally from a systemic perspective. The FHC model of financial conglomeration seems to fit this new architecture relatively better as compared to the banksubsidiary model.

Although the HCM is not decisively superior to the BSM, yet it offers some distinctive advantages as detailed below.

a) As under the HCM, the subsidiaries will not be directly held by the bank, the responsibility to infuse capital in the subsidiaries would rest with the holding company. As such, HCM model is superior in eliminating capital constraints and enabling expansion in other financial services.

b) The HCM model fares better in terms of direct impact of the losses of the subsidiaries, which would be borne by the holding company unlike in the case of BSM where it would be up streamed to the consolidated balance sheet of the bank.

c) Management of individual entities in a disaggregated structure is obviously easier and more effective. Under the HCM, unlike in the case of BSM, the bank's board will not be loaded with the responsibility of managing the group's subsidiaries. 
d) From the systemic perspective, the HCM enables a better regulatory oversight of financial groups in line with the emerging post-crisis consensus of having an identified systemic regulator responsible inter alia for oversight of systemically important financial institutions (SIFI).

e) The HCM offers the requisite variance in regulatory approach for the holding company vis-à-vis the individual entities.

f) In addition, the HCM model allows for an effective resolution of different entities as compared with BSM where liquidation of the parent bank may make the liquidation of subsidiaries inevitable.

\section{Why FHCs/ BHCs in India}

In terms of existing instructions, a bank's aggregate investment in the financial services companies including subsidiaries is limited to $20 \%$ of the paid up capital and reserves of the bank. However, in a FHC/ BHC structure, this restriction will not apply as the investment in subsidiaries and associates will be made directly by the $\mathrm{FHC} / \mathrm{BHC}$. As the subsidiaries are separated from the banks, their growth of the subsidiaries/associates would not be constrained because of capital.

In the case of public sector banks, the Government holding through a $\mathrm{FHC}$ / BHC will not be possible in the existing statutes. However, if statutes were amended to count for effective holding then, the most important advantage in shifting to $\mathrm{FHC} / \mathrm{BHC}$ model would be that the capital requirements of banks' subsidiaries would be de-linked from the banks' capital.

\section{Introduction of FHCs/ BHCs in India - Some Issues}

Legal Issues for FHCs/ BHCs for India

1) Need for a separate law: Some countries have a separate legislation for regulating FHCs/ BHCs. If we have to have only BHCs, the purpose could be achieved perhaps even by amending the BR Act, 1949. However, in case it is decided to go for FHCs by expanding the scope of permissible financial activities by including all possible financial services, a separate Act on the lines of GLB in USA may be required.

2) Minimum threshold for recognizing a BHC for regulatory purposes: In USA, a BHC is a company which directly or indirectly or acting through one or more other persons owns, controls, or has power to vote 25 percent or more of any class of voting securities of a bank and or controls in any manner the election of a majority of the 
directors or trustees of the bank ${ }^{1}$. A suitable threshold will have to be incorporated in the proposed statute in the Indian context too.

3) Permissible activities of FHCs/BHCs: Internationally, there are restrictions on the activities of BHCs or $\mathrm{FHCs}^{2}$. While BHCs are not allowed to invest in non-banking related activities, subject to certain exceptions, restrictions in the case of FHCs mostly relate to investments in non-financial commercial enterprises. Further, the BHCs and FHCs are required to be non-operating in nature. Appropriate, restrictions on these lines will have to be prescribed by us.

4) Cross holdings among FHCs/BHCs: Cross holdings among BHCs would create intractable regulatory problems. Some limits would be necessary in this regard.

\section{Regulatory issues relating to $\mathrm{FHCS} / \mathrm{BHCs}$}

\section{Capital adequacy framework}

Basel-II norms: Capital adequacy framework for FHCs/BHCs would be governed as per Basel-II norms. The capital adequacy framework would be applicable to the BHC at consolidated level wherever the entire group would qualify as the 'banking group'. (If More than, $50 \%$ of the group's assets are banking assets and more than $50 \%$ of the income is derived from the banking activities $)^{3}$. In other cases, the capital adequacy would be applied at the banking subsidiary level.

\section{Ownership of Banking FHCs}

In India, the ownership norms are not the same for the public and private banks. While the provisions of the respective statutes govern the ownership structure of public sector banks, in the case of private sector banks, the ownership and governance framework put in place by RBI regulates it. The exodus by a banking group to the FHC structure would result in the bank becoming a subsidiary of the FHC. As by definition, an FHC will control a bank, keeping with the spirit behind the legal provisions and the ownership and governance framework, therefore, it would be essential to apply the same ownership and governance framework for the banks to their respective FHCs. For example, in order to remain consistent with the provisions of the Nationalisation Acts, in the case of nationalized banks, it would entail Government of India retaining a minimum stake of $51 \%$ in the FHC and foreign

\footnotetext{
${ }^{1}$ Bank Holding Company, Supervision Manual, Federal Reserve, New York, USA

${ }^{2}$ Financial Holding Companies: Bill C-8 and New Options for Financial Conglomerates ( in Canada)

${ }^{3}$ FSI Connect, FSI
} 
investment not exceeding 20\%. Similarly, in the case of a FHC controlling a private sector bank, it would entail the acknowledgement for acquisition or transfer of shares for any acquisition of shares of 5 per cent and above of the paid up capital of the FHC.

\section{Need for a Separate Act}

A dedicated Act has been enacted for regulation of FHCs in most of the countries. In the US, FRB is the regulator of BHCs and FHCs. In Australia, Canada, Cayman Islands, Colombia, Japan, Korea, Singapore, Sweden, and United Kingdom a single regulator oversees the activities of all financial conglomerates as a whole. In the case of Argentina, Austria, Hong Kong, Israel, Philippines, Spain and Switzerland identity of the lead regulator for a financial conglomerate is determined based on the financial conglomerate's major activity. In France, Germany, Italy, Luxembourg, Netherlands, South Africa, Turkey and Uruguay financial conglomerates operate without a single or lead regulator.

In the case of India, RBI Act of 1934 is not deemed adequate to regulate and supervise the FHCs by RBI, as the legal powers are required to regulate comprehensively and exercise consolidated supervision on the FHCs are not provided for in the provisions governing NBFCs contained in the RBI Act. In particular, RBI Act do not confer powers to change the management of the holding company or give direction as to the kind of other subsidiaries etc., collect information from and inspect the subsidiaries of the FHCs and the application of bank-like ownership restrictions on the FHCs.

\section{Conclusion}

Financial conglomerates have evolved predominantly over the second half of the twentieth century, and have become exceptionally significant in recent years. The major economic benefits from conglomerates are the suitability to realize potential economies of scale and scope and to gain synergies across complementary business lines. These economies result in enhanced operational efficiency and effectiveness owing to lesser costs, reduced prices, and enriched innovation in products and services. Though the empirical benefits of such financial conglomerates are uncertain, of late these organizations indeed have gained in prominence. Yet, there seems to be a steady trend towards increasing conglomeration in several countries. It is also opined by some observers that regulatory authorities have encouraged consolidation in the financial services industry in order to facilitate enhanced diversification, capitalization, and investments in banking information technology, and to lessen the supervisory burden 
where banking organizations are larger and more visible (and thus open to increased public scrutiny).

Indian banking sector is passing through another crucial phase in its evolution with the Reserve Bank of India proposing the formation of holding companies in banking groups. RBI has suggested that a financial holding company (FHC) or a banking holding company (BHC) will offer considerable advantages as the banks will be much better protected against possible adverse effects from the activities of their non-banking financial subsidiaries. In view of the above, the financial holding company (FHC) model ought to be pursued as a preferred model for the financial sector in India. In addition, the FHC model can be extended to all large financial groups - irrespective of whether they contain a bank or not. Therefore, there can be Banking FHCs controlling a bank and Non-banking FHCs, which do not contain a bank in the group.

\section{References:}

Black, Fischer \& Miller, Merton H \& Posner, Richard A (1978), An Approach to the Regulation of Bank Holding Companies, Journal of Business, University of Chicago Press, vol. 51(3), pages 379-412, July

Freixas, Xavier \& Loranth, Gyongyi \& Morrison, Alan D. (2007), Regulating financial conglomerates, Journal of Financial Intermediation, Elsevier, vol. 16(4), pages 479514 , October

Howell E. Jackson, (1997), The Regulation of Financial Holding Companies, Available at: cyber.law.harvard.edu/rfi/papers/fhc\%20paper.pdf

Kevin J. Stiroh, (2000), How did bank holding companies prosper in the 1990s, Journal of Banking \& Finance, 24 (2000) 1703 \pm 1745

Peter G. Klein \& Marc R. Saidenberg. (1997), "Diversification, Organization, and Efficiency: Evidence from Bank Holding Companies," Center for Financial Institutions Working Papers 97-27, Wharton School Center for Financial Institutions, University of Pennsylvania

PRC 3890-Banking Laws and Regulations, (2003), Final Report, Section VII - Financial Conglomerates, International Law Institute, $15^{\text {th }}$ December.

RBI, (2011), Report of the Working Group on Introduction of Financial Holding Company Structure in India, Reserve Bank of India, $4^{\text {th }}$ May.

Stiroh, K.J. \& Rumble A. (2006), The dark side of diversification: The case of US financial holding companies, Journal of Banking \& Finance, 30 (2006) 2131-2161 